\title{
The Effect of Online Learning Model (E-Learning) on the Prospective Teachers' Concept Mastery
}

\author{
Ni Nyoman Sri Putu Verawati*, Hairunnisyah Sahidu, Ahmad Harjono, Hikmawati, I \\ Wayan Gunada \\ Physics Education Study Program, Faculty of Teacher Training and Education, University of \\ Mataram, Jl. Majapahit No 62 Mataram, 83125, Indonesia \\ *Corresponding Author e-mail: veyra@unram.ac.id
}

Received: October 2021; Revised: November 2021; Published: December 2021

\begin{abstract}
During the Covid-19 pandemic, face-to-face learning has been replaced with online learning (e-learning). The learning process with this mode must be able to support the learning objectives towards understanding the concept. This study aims to explore the effect of e-learning on concept mastery in prospective teachers. In this study, we conducted a one group pretest posttest design, where one class group was used as the research sample and was given a pretest, treatment, and posttest. The sample was taken purposively with the criteria of prospective teacher students taking fundamental physics courses on motion kinematics material. The number of research samples was 23 prospective teachers at the Faculty of Teacher Training and Education, University of Mataram - Indonesia. The instrument in the form of an essay test is used to measure the understanding of the concept. Analysis of research data used descriptive statistical analysis (pair t-test) to test the research hypothesis. The results of the pair t-test showed a significance of $p=0.000(<0.05)$, this means that there is a significant difference between the pretest and posttest scores after the implementation of e-learning. The interpretation leads to the effect of online learning mode (e-learning) on the concept mastery ability of prospective teachers.
\end{abstract}

Keywords: Covid-19 pandemic, e-learning, concept mastery

How to Cite: Verawati, N., Sahidu, H., Harjono, A., Hikmawati, H., \& Gunada, I. (2021). The Effect of Online Learning Model (E-Learning) on the Prospective Teachers' Concept Mastery. Prisma Sains : Jurnal Pengkajian Ilmu dan Pembelajaran Matematika dan IPA IKIP Mataram, 9(2), 253-258. doi:https://doi.org/10.33394/jps.v9i2.4388

\section{INTRODUCTION}

Electronic learning (e-learning) is currently used as the main choice of the learning process in the midst of the Covid-19 pandemic that has hit almost all parts of the world, and its use has become a topic of conversation and is investigated (researched) globally. Elearning or electronic learning by utilizing the internet is widely known as online learning. The use of e-learning on the one hand makes educators (teachers and lecturers) work hard to help students achieve the expected learning outcomes with interactive content in the learning process. Actually e-learning has long been used in most well-known universities around the world (before the Covid-19 pandemic), it's just that in the midst of the current pandemic its use is more massive and intensive. Any involvement or use of internet/intranet systems in the learning process is called e-learning (Fee, 2005). Any content that is packaged, presented, modified, or activated by electronic technology through the internet network to achieve learning objectives is referred to as electronic learning (e-learning) (Cheng, 2006; Jethro et al., 2012). As an educational system, tool and media, e-learning has grown and developed significantly along with the development of technology. 
Conventionally, universities (especially in Indonesia) have been applying various learning models/methods/strategies in providing learning experiences by relying on face-toface interactions. However, along with technological advances, this has shifted to a virtual learning system (e-learning), especially during the Covid-19 pandemic which is currently hitting and has a direct impact on the learning process. The interest in e-learning in its use is in line with the changing lifestyles and demands of society in the 21st century. The use of interactive multimode teaching in the 21 st century is urgently needed to improve the learning process for students (Prayogi et al., 2018), one of which is e-learning (Haghparast et al., 2014). Time efficiency of its use is an advantage of e-learning systems (Benson \& Samarawickrema, 2009). Previous studies (Gharib et al., 2016) have shown that e-learning can improve students' thinking skills and their motivation to learn. This motivation is found in the framework of interaction, collaboration, and feedback between teachers and students and also between students (Nehme, 2010). The level of student participation through online interactions resulted in higher levels of persistence and cognitive involvement in completing assignments (Wlodkowski, 2005).

Specific knowledge and skills can be achieved using electronic technology with digital content such as in E-learning systems (Kahiigi et al., 2008). In addition, the independence and motivation of learners can be created when compared to traditional learning without elearning (El-Seoud et al., 2014). This is the reason for the e-learning system as a new feature in the pedagogical dimension. The emphasis of e-learning on learning is not only emphasized for the purpose of learning motivation, but also in the realm of the content of the material being taught, where students are expected to mastery the concepts of the material being taught. Mastery of concepts that are more generally emphasized on mastery of knowledge at Bloom's cognitive level, starting from knowledge (knowledge) to evaluation (evaluate) (Nugraha et al., 2016). Students who master the concept can identify and solve new, more varied problems (Alighiri et al., 2018; Rahhou et al., 2015). The learning process that represents the learning objectives must support the understanding of the concepts to be achieved, one of which is e-learning. This study aims to explore the effect of e-learning on concept mastery in prospective teachers.

\section{METHOD}

This research is an experimental study (pre-experimental) with a "one group pretest posttest design" (Fraenkel et al., 2012). One class group was used as the research sample which was given a pretest (pretest), learning treatment (treatment), and a final test (posttest). The sample was taken purposively with the criteria of prospective teacher students taking fundamental physics courses on motion kinematics material. The number of research samples was 23 prospective teachers at the Faculty of Teacher Training and Education, University of Mataram - Indonesia.

The students' concept mastery ability as measured in this study, is in the cognitive aspects of level C2 (understanding) to C6 (evaluation). The instrument is a test (essay test) which consists of 5 test items. The range of concept mastery scores is as presented in Table 1. Furthermore, the increase in the concept mastery ability scores of prospective teachers was analyzed using the n-gain equation (Hake, 1999), with the criteria of high ( $x>0.7)$, medium (x; $0.3-0.7)$, and low $(x<0.3)$.

Table 1. Scoring ranges and criteria for concepts mastery

\begin{tabular}{cc}
\hline Score range & Criteria \\
\hline$L A \geq 80$ & Very good \\
$60 \leq L A<80$ & Good \\
$40<L A \leq 60$ & Sufficient \\
$20<L A \leq 40$ & Less \\
$L A \leq 20$ & Fail \\
\hline
\end{tabular}


Statistical data analysis (inferential statistics) was conducted to analyze the concept mastery ability test data. The test used is a paired t-test (pair t-test) which aims to examine the effect of treatment (e-learning implementation) on students' conceptual mastery abilities. The criterion for rejecting $\mathrm{HO}$ in this study is if the statistical significance or $\mathrm{p}$-value (t-test) is less than 0.05 . If $\mathrm{H} 0$ is rejected then $\mathrm{H} 1$ is accepted, or vice versa. The requirement before the $\mathrm{t}-$ test is that the data is normally distributed with the criteria if the significance value ( $p$-value) is greater than 0.05. The normality test of the data used the Kolmogorov-Smirnov test. All data analysis statistically using SPSS tool.

\section{RESULTS AND DISCUSSION}

E-learning has been massively used in higher education level learning in Indonesia as a result of the Covid-19 pandemic that has hit the world. Theoretical studies show that the use of e-learning can motivate students in learning. However, the emphasis of e-learning on learning is not only for the purpose of learning motivation but also in the realm of the content of the material being taught, where students are expected to be able to master the concepts of the material being taught. Therefore, the learning process that represents the learning objectives must support the understanding of the concept to be achieved, in this research it is e-learning. The effect of e-learning implementation is explored further in order to become empirical evidence whether its implementation can increase students' mastery of concepts or vice versa, so that it can be considered for widespread implementation. Descriptive analysis of the concept mastery ability of prospective teachers are presented in Table 2 and Table 3.

Table 2. The result of concept mastery of each prospective teachers

\begin{tabular}{|c|c|c|c|c|c|c|}
\hline PTs & Pretest score & Criteria & Posttest score & Criteria & n-gain & Criteria \\
\hline M 1 & 40.00 & Less & 67.50 & Good & 0.46 & Moderate \\
\hline M 2 & 25.00 & Less & 90.00 & Very good & 0.87 & High \\
\hline M 3 & 45.00 & Sufficient & 75.00 & Good & 0.55 & Moderate \\
\hline M 4 & 27.50 & Less & 97.50 & Very good & 0.97 & High \\
\hline M 5 & 37.50 & Less & 90.00 & Very good & 0.84 & High \\
\hline M 6 & 22.50 & Less & 90.00 & Very good & 0.87 & High \\
\hline M 7 & 67.50 & Good & 85.00 & Very good & 0.54 & Moderate \\
\hline M 8 & 57.50 & Sufficient & 82.50 & Very good & 0.59 & Moderate \\
\hline M 9 & 32.50 & Less & 82.50 & Very good & 0.74 & High \\
\hline M 10 & 12.50 & Fail & 87.50 & Very good & 0.86 & High \\
\hline M 11 & 37.50 & Less & 80.00 & Good & 0.68 & Moderate \\
\hline M 12 & 25.00 & Less & 85.00 & Very good & 0.80 & High \\
\hline M 13 & 62.50 & Good & 100.00 & Very good & 0.98 & High \\
\hline M 14 & 40.00 & Less & 90.00 & Very good & 0.83 & High \\
\hline M 15 & 45.00 & Sufficient & 95.00 & Very good & 0.91 & High \\
\hline M 16 & 75.00 & Good & 97.50 & Very good & 0.90 & High \\
\hline M 17 & 17.50 & Fail & 90.00 & Very good & 0.88 & High \\
\hline M 18 & 22.50 & Less & 95.00 & Very good & 0.94 & High \\
\hline M 19 & 40.00 & Less & 85.00 & Very good & 0.75 & High \\
\hline M 20 & 15.00 & Fail & 67.50 & Good & 0.62 & Moderate \\
\hline M 21 & 45.00 & Sufficient & 87.50 & Very good & 0.77 & High \\
\hline M 22 & 37.50 & Less & 97.50 & Very good & 0.96 & High \\
\hline M 23 & 22.50 & Less & 97.50 & Very good & 0.97 & High \\
\hline Averages & 37.06 & Less & 87.61 & Very good & 0.79 & High \\
\hline
\end{tabular}

Table 3. The descriptive analysis results of the concept mastery

\begin{tabular}{|c|c|c|c|c|c|}
\hline \multicolumn{2}{|c|}{ Data variable } & Mean & $\mathrm{N}$ & Std. Deviation & Std. Error Mean \\
\hline \multicolumn{2}{|c|}{ Pair 1 Pretest } & 37.06 & 23 & 16.73 & 3.49 \\
\hline & Posttest & 87.61 & 23 & 8.99 & 1.88 \\
\hline
\end{tabular}


The results in Table 2 and Table 3 show that the average score of mastery of student teacher concepts on the pretest is 37.06 with the criterion of "less," and the posttest average score of 87.61 with the criterion of "very good." Analysis of the increase in the score (n-gain) of concept mastery is in the "high" criteria. Furthermore, statistical analysis, namely paired ttest (pair t-test) was carried out to test the effect of treatment (e-learning implementation) on students' conceptual mastery abilities, as presented in Table 4. Prior to pair t-test, data normality test was performed using Kolmogorov-Smirnov test. The results show that the significance is $0.200(>0.05)$, this indicates the data variance is normally distributed.

Table 4. The pair t-test result

\begin{tabular}{lccc}
\hline Data variable & $\mathrm{t}$ & df & Sig. (2-tailed) \\
\hline Pretes-Posttest & -13.553 & 22 & 0.000 \\
\hline
\end{tabular}

The results of the pair t-test showed a significance of $p=0.000(<0.05)$, according to the criteria for testing this hypothesis, meaning that there was a significant difference between the pretest and posttest scores after the implementation of e-learning. The interpretation leads to the effect of online learning mode (e-learning) on the concept mastery ability of prospective teachers.

In general, descriptive analysis on the concept mastery of prospective teachers who are taught by online mode (e-learning) shows a very good performance, this is carried out in the kinematics of motion material (see Table 2 and Table 3). The e-learning mode empirically shows a very good concept mastery performance, and this result proves that face-to-face interaction is not an obstacle in the learning process and has been replaced by e-learning mode. These results are in line with previous studies (Sadikin \& Hamidah, 2020) that the use of the internet and multimedia technology in e-learning platforms can overhaul the ways of transferring knowledge in traditional classrooms and can be an alternative to learning that is carried out today. Multimode learning interactions can occur through e-learning systems (Maulah, et al., 2020; Pangondian, et al., 2019). The interactive process becomes an important point when learning outcomes for the purpose of understanding concepts are emphasized.
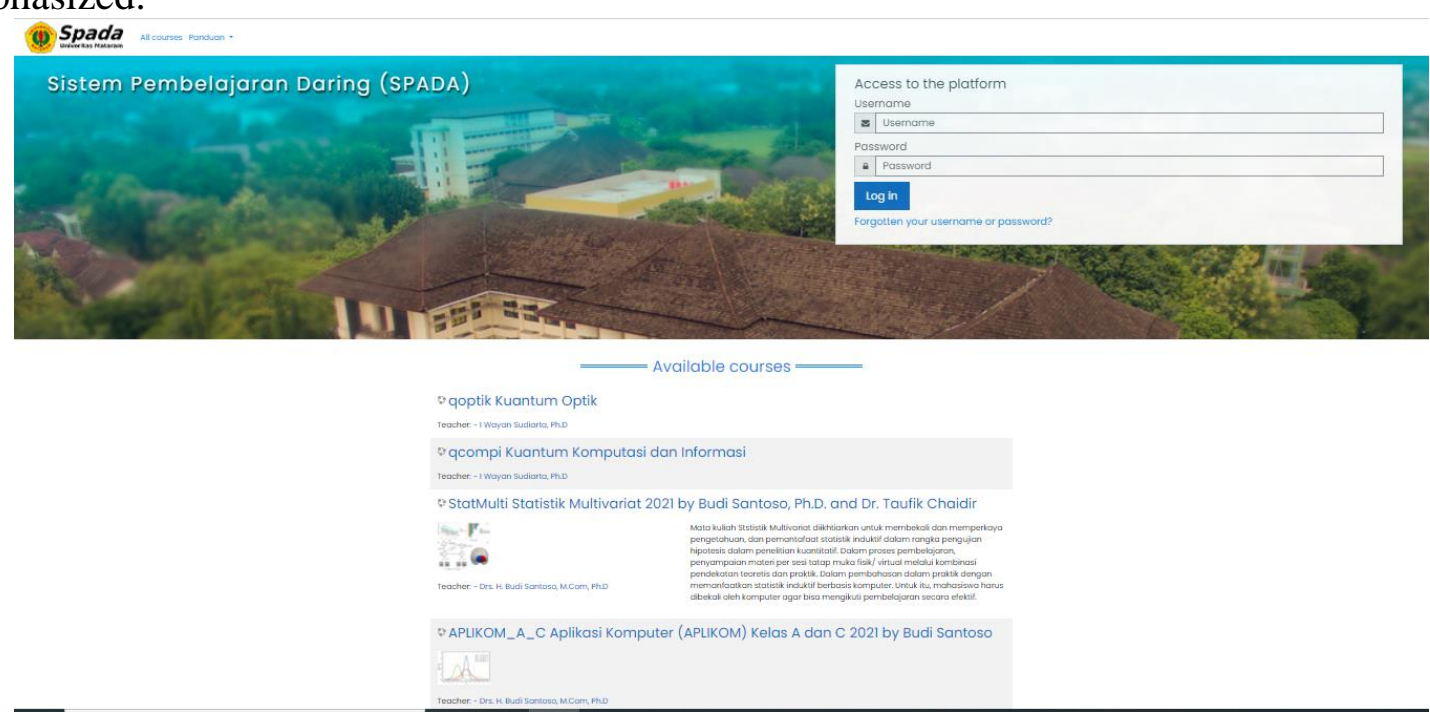

Figure 1. LMS applied at the University of Mataram

The introduction of e-learning platforms has reduced many difficulties associated with the teaching and learning process (Mohammed et al., 2017). On the one hand, the current Covid-19 pandemic has hit the world, including Indonesia. As the number of positive COVID-19 patients in Indonesia continues to increase, the government through the Ministry 
of Education and Culture has implemented a learning from home program for all levels of education, including higher education. Universities are required to be able to organize online learning (Firman \& Rahayu, 2020) by utilizing internet media. Referring to this policy, the University of Mataram as a higher education provider eliminates conventional (face-to-face) lectures and replaces it with an online learning system utilizing synchronous or asynchronous internet technology and media. The advantages of e-learning are used to develop students' mastery of concepts. For this purpose, lecturers at the University of Mataram use a learning management system (LMS) as shown in Figure 1. E-learning is expected to be a momentum to effectively develop technology-based innovative learning to replace learning with face-toface systems in the classroom. (teacher-directed learning) (Saifuddin, 2017).

\section{CONCLUSION}

A study on the effect of e-learning on concept mastery in prospective teachers has been carried out. The average score of student teacher concept mastery on the pretest was 37.06 with the criterion of "less," and the posttest average score of 87.61 with the criterion of "very good." Analysis of the increase in the score (n-gain) of concept mastery is in the "high" criteria. The results of the pair t-test showed a significance of $p=0.000(<0.05)$, meaning that there was a significant difference between the pretest and posttest scores after the implementation of e-learning. The interpretation leads to the effect of online learning mode (e-learning) on the ability to concept mastery in prospective teachers.

\section{ACKNOWLEDGMENT}

This research was funded from the DIPA BLU (PNBP) of Mataram University, for fiscal year 2021 .

\section{REFERENCES}

Alighiri, D., Drastisianti, A., \& Susilaningsih, E. (2018). Pemahaman konsep siswa materi larutan penyangga dalam pembelajaran multiple representasi. Jurnal Inovasi Pendidikan Kimia, 12(2), 192-200.

Benson, R., \& Samarawickrema, G. (2009). Addressing the context of elearning: using transactional distance theory of inform design. Distance Education, 30, 5-21.

Cheng, K. (2006). A research study on students' level of acceptance in applying e-learning for business courses - A case study on a technical college in Taiwan. Journal of American Academy of Business, 8(2), 265-270.

El-Seoud, M. S. A., Taj-Eddin, I. A. T. F., \& Seddiek, N. (2014). E-learning and students' motivation: A research study on the effect of e-learning on higher education. International Journal of Emerging Technologies in Learning, 9(4), 20-26.

Fee, K. H. (2005). Delivering e-learning: A complete strategy for design application and assessment. London and Philadelphea: Kogan Page.

Firman, F., \& Rahayu, S. 2020. Pembelajaran Online di Tengah Pandemi Covid-19. Indonesian Journal of Educational Science (IJES), 2 (2), 81-89.

Fraenkel, J. R., Wallen, N.E., \& Hyun, H.H. (2012). How to design and evaluate research in education (8th ed). New York: McGraw-Hill.

Gharib, M., Zolfaghari, M., Mojtahedzadeh, R., Mohammadi, A., \& Gharib, A. (2016). Promotion of critical thinking in e-learning: A qualitative study on the experiences of instructors and students. Advances in Medical Education Pract Practice, 7, 271-279.

Haghparast, M., Nasaruddin, F. H. \& Abdullah, N. (2014). Cultivating critical thinking through e-learning environment and tools: A review. Procedia-Social and Behavioral Sciences, 129, 527-535.

Helmi, Rustaman, N. Y., Tapilouw, F. S., \& Hidayat, T. (2019). Students' concept mastery: Reasoning ability and concept mastery of evolution. Indonesian Journal of Social Research (IJSR), 1(1), 23-29. https://doi.org/10.30997/ijsr.v1i1.7 
Kahiigi, E. K., Ekenberg, L., Hansson, H., Tusubira, F. F., \& Danielson, M. (2008). Exploring the e-learning state of art. The Electronic Journal of e-Learning, 6(2), 7788.

Jethro, O. O., Grace, A. M., \& Thomas, A. K. (2012). E-learning and its effects on teaching and learning in a global age. International Journal of Academic Research in Business and Social Sciences, 2(1), 203-210.

Kuntarto, E. 2017. Keefektifan Model Pembelajaran Daring dalam Perkuliahan Bahasa Indonesia di Perguruan Tinggi. Indonesian Language Education and Literature, 3(1), 99-110.

Maulah, S., Nurul, F. \& Ummah, N.R. 2020. Persepsi Mahasiswa Biologi terhadap Perkuliahan Daring sebagai Sarana Pembelajaran Selama Pandemi Covid-19. ALVEOLI: Jurnal Pendidikan Biologi, 1(2), 49-61.

Mohammed, A., Kumar, S., Saleh, B. M., \& Shuaibu, A. (2017). E-learning: A tool for enhancing teaching and learning in educational institutes. International Journal of Computer Science and Information Technologies, 8(2), 217-221.

Nehme, M. (2010). E-Learning and students' motivation. Legal Education Review, 20(1), 223-239.

Nugraha, M.G., Karniawati, I., Rusdiana, D. \& Kirana K.H. (2016). Combination of inquiry learning model and computer simulation to improve mastery concept and the correlation with critical thinking skills (CTS). AIP Conference Proceedings 1708, 1-6.

Rahhou, A., Kaddari, F., Elachqar, A., \& Oudrhiri, M. (2015). Infinity small concepts in the learning of chemistry. Procedia - Social and Behavioral Sciences, 191, 1337-1343.

Pangondian, R. A., Santosa, P. I., \& Nugroho, E. 2019. Faktor-Faktor Yang Mempengaruhi Kesuksesan Pembelajaran Daring Dalam Revolusi Industri 4.0. Seminar Nasional Teknologi Komputer \& Sains (SAINTEKS), 1 (1), 56-60.

Prayogi, S., Yuanita, L., \& Wasis. (2018). Critical inquiry based learning: Model of learning to promote critical thinking ability of pre-service teachers. Journal of Physics: Conf. Series 947 1-6.

Sadikin, A. \& Hamidah, A. 2020. Pembelajaran Daring di Tengah Wabah Covid-19. BIODIK: Jurnal Ilmiah Pendidikan Biologi, 6(2), 214-224.

Saifuddin, M.F. 2017. E-Learning dalam Persepsi Mahasiswa. Jurnal Varia Pendidikan, 29 (2), 102-109.

Wlodkowski, R. J. (2005). Adults in modern society are on a lifelong Educational Journey.http://userpages.umbc.edu/ koconne1/605TheAdultLearner/elearning.htm

Yuniarti, R.D. 2010. Potensi E-Learning melalui Sistem Kuliah On-Line dalam Meningkatkan Kualitas Pembelajaran di Prodi Tata Niaga Jurusan Pendidikan Ekonomi FPEB-UPI. Jurnal ANAJERIAL, 8 (16), 66-77.

Zhafira, N.H., Ertika, Y. \& Chairiyaton. 2020. Persepsi Mahasiswa terhadap Perkuliahan Daring sebagai Sarana Pembelajaran Selama Masa Karantina Covid-19. Jurnal Bisnis dan Kajian Strategi Manajemen, 4(1), 37-45. 